\title{
Optical characterization of chromophoric dissolved organic matter at eutrophic and oligotrophic parts of a semi-enclosed bay (Izmir, Aegean Sea)
}

\author{
Yarı-kapalı bir körfezin (İzmir, Ege Denizi) ötrofik ve oligotrofik \\ kısımlarında kromoforik çözünmüş organik maddenin optik \\ karakterizasyonu
}

\author{
Hakan Alyürük ${ }^{1 *}$ • Aynur Kontaş² \\ 1 Dokuz Eylül University, Institute of Marine Sciences and Technology, 35340, Inciraltı, İzmir, Turkey \\ ${ }^{2}$ Dokuz Eylül University, Institute of Marine Sciences and Technology, 35340, Inciraltı, Izmir, Turkey \\ https://orcid.org/0000-0001-8632-4281 \\ https://orcid.org/0000-0002-6273-1568
}

\section{How to cite this paper:}

Alyürük, H. \& Kontaş, A. (2021). Optical characterization of chromophoric dissolved organic matter at eutrophic and oligotrophic parts of a semi-enclosed bay (izmir, Aegean Sea). Ege Journal of Fisheries and Aquatic Sciences, 38(2), 199-210. DOI: 10.12714/egejfas.38.2.09

Abstract: Optical characterization of chromophoric dissolved organic matter (CDOM) from Izmir Bay (Aegean Sea) waters was investigated. For sampling, surface and subsurface seawater from 7 stations were collected in summer 2015. Excitation-emission matrix (EEM) spectra of each sample were recorded on a fluorescence spectrophotometer. The results showed that dissolved organic carbon (DOC) concentrations and EEM peaks were increased from the outer bay to inner bay stations. EEM peaks indicated the presence of both humic-like and protein-like components which were higher at middle-inner bays than outer bay. Spearman's rank correlation coefficients for EEM peak intensities and DOC concentrations were highly positive $(p<0.05)$. HIX found between 0.73 3.51 , whereas BIX ranged from 0.31 to 0.96 in the bay. Humification degree of CDOM in the middle-inner bays were higher compared to outer bay stations. High HIX values in the middle-inner bays could be linked to the presence of Melez stream (heavily polluted), other streams, rain run-offs and maritime activities at İmir Bay. High BIX values in the middle-inner bays indicated presence of freshly produced DOM from bacterial origin. Optical characterization of CDOM could be used for tracing fluorescent DOM components and determining different DOM sources (autochthonous or allochthonous) in further studies.

Keywords: Chromophoric dissolved organic matter, dissolved organic carbon, fluorescence, seawater, İmir Bay

Öz: Bu çalışmada, İzmir Körfezi (Ege Denizi)'nden alınan deniz suyunda kromoforik çözünmüş organik madde (KÇOM)'nin optik karakterizasyonu araştırımıştır. Deniz suyu örnekleri 7 istasyonda yüzey ve yüzey-altı derinliklerden 2015 ylı yaz mevsiminde toplanmıştır. Her bir örneğin uyarma-emisyon matris (UEM) spektrumu bir floresans spektrofotometresi araciığılla kaydedilmiştir. Sonuçlar, çözünmüş organik karbon (ÇOK) ve UEM pik şiddetlerinin dı̧̧ körfezden iç körfeze doğru arttığını göstermiştir. UEM pikleri, hem hümik asit benzeri hem de protein benzeri organik madde bileşenlerinin orta-iç körfezlerde dış körfeze kıyasla daha yüksek olduğunu ortaya koymuştur. Spearman'ın sıralama korelasyonu testleri sonucunda UEM pik şiddetleri ve ÇOK konsantrasyonları arasında yüksek pozitif ilişki bulunduğu saptanmıştır $(p<0.05)$. Körfez genelinde hümikleşme indeksi $(H I)$ 0.73-3.51 aralığında, biyolojik indeks (BI) ise 0.31-0.96 aralığında değişim göstermiştir. KÇOM'a ait hümikleşme derecesi orta-iç körfezlerde dış körfeze kıyasla daha yüksek tespit edilmiştir. Orta-iç körfezlerde gözlenen yüksek HI değerlerinin yüksek kirlilik yükü taşıyan Melez çayının varı̆ı̆ı, iç körfeze ulaşan diğer yüzey sularının varlığı, yağmur ile denize sürüklenebilen karasal organik maddeler ve İzmir Körfezi'ndeki denizcilik aktiviteleri ile ilişkili olduğu düşünülmektedir. Orta-iç körfezlerde gözlenen yüksek BI değerleri ise özellikle bakteriyel kökenli ve yeni üretilmiş çözünmüş organik madde üretimi ile ilişkilendirilebilir. KÇOM'un optik karakterizasyonu, gelecek çalışmalarda çözünmüş organik madde içerisindeki floresans özellikteki bileşenlerin takip edilebilmesi ve çeşitli organik madde kaynaklarının (otokton veya allokton) belirlenmesi amacıyla kullanilabilir.

Anahtar kelimeler: Kromoforik çözünmüş organik madde, çözünmüş organik karbon, floresans, deniz suyu, İzmir Körfezi

\section{INTRODUCTION}

Dissolved organic matter (DOM) is a heterogeneous compound pool that is composed of complex organic molecules within seawater. DOM could be originated from terrestrial processes (allochthonous) or in situ marine (autochthonous) sources (Hedges, 2002; Libes, 2009). DOM pool contains vast amounts of biomolecules at different chemical structures and molecular sizes. Humic acids, fulvic acids, lignins, amino acids, carbohydrates, lipids, fatty acids, and sterols are such examples to most abundant biomolecules in DOM. Primary production and exudates of phytoplankton, sloppy feeding of metazoan grazers, viral cell lysis, egesta of protists and metezoans, and extracellular hydrolysis of POM by bacteria are the main sources of in situ DOM production (Aparicio et al., 2016; Brussaard, 2004; Motegi et al., 2009; Ortega-Retuerta et al., 2009; Ridgwell and Arndt, 2015; Romera-Castillo et al., 2011a; Sala and Güde, 2004; Sarmento et al., 2013; Zeri et al., 2014). Following its release to the marine environment, DOM is constantly circulated, transferred, 
and subjected to transformations within the marine environment. The factors controlling its transformations could be photochemical processes (Mopper et al., 1991; Santos et al., 2014; Sulzberger and Durisch-Kaiser, 2009; Vähätalo and Wetzel, 2004; Zhang et al., 2013), sorption in sediments by flocculation (Cauwet, 2002), sorption by sinking particles (Carlson and Hansell, 2015; Hansell et al., 2009), sorption by metal-oxides (Couturier et al., 2016), physical processes (Boyd and Osburn, 2004; Cauwet, 2002; Dixon et al., 2014), and bacterial processes (Boyd and Osburn, 2004; Nelson et al., 2004; Santos et al., 2014; Vähätalo and Wetzel, 2004). Significant contributions of anthropogenic inputs to the DOM pool in coastal waters were also reported (Hong et al., 2005; Sun et al., 2014; Tedetti et al., 2011; Tzortziou et al., 2015; Wang et al., 2014), which in turn, these may lead to eutrophication, hypoxia or harmful algal blooms (Anderson et al., 2002; Cloern, 2001; Conley et al., 2009; Davidson et al., 2012; Davidson et al., 2014; Heisler et al., 2008; Jessen et al., 2015; Korpinen and Bonsdorff 2015; Sellner et al., 2003). Therefore, understanding and monitoring of DOM sources and its transformations in coastal waters is of great importance for elucidating the fates of DOM components and the assessment of ecological status of the marine environment.

In recent studies, optical characterization of DOM has been used frequently as it provides information about autochthonous or allochthonous sources and its transformations by applying rapid and inexpensive methods (Coble et al., 1990; Kowalczuk et al., 2010; Kowalczuk et al., 2015; Lonborg et al., 2015; Lu et al., 2015; Nieto-Cid et al., 2006; Romera-Castillo et al., 2011b; Romera-Castillo et al., 2013; Yang et al., 2016; Zeri et al., 2014). The fraction of DOM that is able to absorb and/or emit light is called as chromophoric dissolved organic matter (CDOM). The light spectra of CDOM is recorded by applying simultaneous (or three dimensional) excitation-emission matrix (EEM) spectroscopy with a fluorometer. Parallel factor analysis (PARAFAC) is used to extract the characteristic peaks of humic-like or protein-like compounds (Murphy et al., 2013; Stedmon et al., 2003). Fluorometric characterization of CDOM, when combined with absorption measurements, not only provides information about its sources and transformation but also helps to understand its relations with bacterial and photochemical processes (Guo et al., 2007; Kowalczuk et al., 2003; Lu et al., 2015; Murphy et al., 2008; Yamashita and Tanoue, 2003).

İzmir Bay is located at the Eastern coast of the Aegean Sea. It has an $L$ shaped structure, and its entrance is oriented to the north with its longer part. The hydrography of the Izmir Bay is influenced from several factors: exchanges between the atmosphere and the sea, exchange of water masses with the Aegean Sea, freshwater inputs with anthropogenic loads, topography of the bay, sea level changes, wind-driven circulations of water masses and winter convection (Sayin, 2003). Under the influence of these factors, water masses in the İzmir Bay could be divided into three different parts: Inner Bay water (anthropogenically polluted), Outer Bay water (the water mass influenced from Gediz River and Aegean Sea, the upwelling water at Gülbahçe Bay, and the water mass located at salt production area), and Middle Bay water (connects Outer Bay to Inner Bay) (Sayin, 2003). Remarkable differences for DOC, Chl-a, dissolved inorganic nitrogen (DIN), and dissolved inorganic phosphorus (DIP) levels were reported at outer, middle and inner bay stations in the previous studies (Kontas et al., 2004; Kucuksezgin et al., 2005; Sunlu et al., 2012). Also, algal blooms and eutrophication have been observed in the inner bay that is under the influence of anthropogenic inputs (Ozkan et al., 2008; Sunlu et al., 2011). For example, temporarily, high abundances of Ceratium furca var. eugrammum, Cylindrotheca closterium, Prorocentrum micans and Noctiluca scintillans biomasses have been observed in the range of 2-5 $\mu \mathrm{M} \mathrm{C}$ (Sunlu et al., 2007). However, there are no studies on the optical characterization of DOM, and its possible sources in the Izmir Bay. The aim of this study was to investigate the optical characteristics of CDOM in middle-inner (eutrophic) and outer (oligotrophic) parts of Izmir Bay with dissolved organic carbon (DOC) levels, humification index (HIX) and biological index (BIX).

\section{MATERIAL AND METHODS}

\section{Seawater sampling}

The seawater samples were collected from surface and subsurface (5 m) depths at 7 stations in İzmir Bay (Figure 1) in summer 2015. The sampling stations were selected according to previous observations of physical and chemical characteristics of water masses in the bay (Kontas et al., 2004; Kucuksezgin et al., 2005; Sayin, 2003). The samples were collected with a $1.7 \mathrm{~L}$ Nansen bottle. The samples were immediately filtrated from $47 \mathrm{~mm}$ Whatman GF/F $(0.7 \mu \mathrm{m})$ glass fiber filters and filtrated samples were stored frozen at $-20^{\circ} \mathrm{C}$ until the analyses in the laboratory.

\section{Dissolved organic carbon analysis}

The detection principle of DOC (measured as $\mathrm{CO}_{2}$ ) was based on the discoloration of buffered phenolphthalein solution proportionally to the $\mathrm{CO}_{2}$ concentration (Gershey et al., 1979; Schreurs, 1978). The analysis was performed on a continuous flow nutrient analyzer (San Plus, Skalar) according to instructions of the manufacturer (Cat.No: 311-412). First, 0.06 $\mathrm{N}$ sulfuric acid was added to the sample. Then, digestion reagent was added, and UV digestion was applied. Following the digestion, hydroxylammonium chloride solution was introduced and the $\mathrm{CO}_{2}$ was separated from reaction mixture with a gas dialysis membrane. The liberated $\mathrm{CO}_{2}$ was reacted with the $1 \%$ phenolphthalein buffer solution. Colorimetric reading was performed at $550 \mathrm{~nm}$. Potassium hydrogen phthalate was used as organic carbon standard. Accuracy of the method was checked using potassium hydrogen phthalate at every 10 sample readings. Synthetic seawater including $\mathrm{NaCl}, \mathrm{MgSO}_{4}$ and Milli-Q water was used as blank. The system was washed with Milli-Q water until the low and stable instrumental blank. The detection limit of the method was 16 $\mu \mathrm{MC}$. 


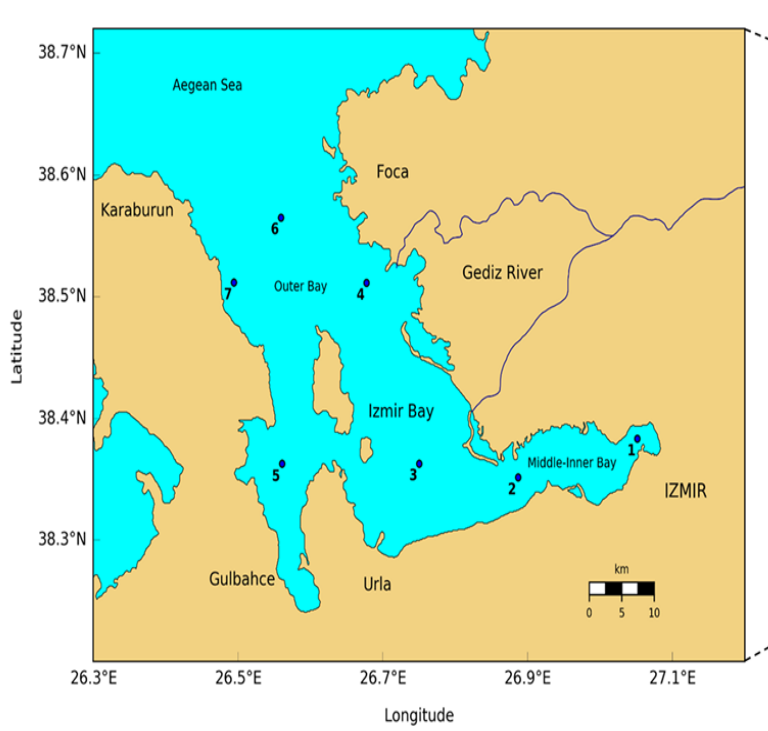

Figure 1. Sampling stations at İzmir Bay, Aegean Sea

\section{Characterization of CDOM}

EEM spectrums were recorded with an Agilent Cary Eclipse Fluorescence Spectrophotometer. EEM spectra were collected at excitation wavelengths of $230-500 \mathrm{~nm}$ and emission wavelengths of $250-600 \mathrm{~nm}$ with a spectral resolution of $2 \mathrm{~nm}$. EEM spectra of Milli-Q water was subtracted from the EEM spectra of samples to remove scattering effects of water (Chari et al., 2012). Raman normalization was applied to normalize the data for comparability (Chari et al., 2012; Murphy et al., 2010; Stedmon et al., 2003) and fluorescence intensities were represented as Raman Units (RU). Raman normalization was performed by using Raman peak area (Eq. 1, $\lambda$ ex $=350 \mathrm{~nm}$, $\lambda e m=381-421 \mathrm{~nm})$ and dividing fluorescence intensity to Raman peak area (Eq. 2). EEM peaks of samples were determined according to Coble (1996) (Table 1). Postprocessing of EEM spectrums were performed with modified PLOTEEM script in R (Lapworth and Kinniburgh, 2009; R Core Team, 2016). EEM peaks were extracted according to "algorithm-based approach" by selecting the peak points with maximum fluorescence intensities at defined emission regions (Korak et al., 2014).

$$
\begin{aligned}
& A_{R}^{350}=\int_{381}^{426} I\left(\lambda_{\mathrm{em}}\right) \mathrm{d} \lambda_{\mathrm{em}} \\
& I(\mathrm{RU})=\frac{1}{A_{R}^{350}} I(\mathrm{AU})
\end{aligned}
$$

where $A_{R}{ }^{350}$ indicates area under emission spectrum between 381 and $421 \mathrm{~nm}$ at excitation wavelength of $350 \mathrm{~nm}$, $I\left(\lambda_{\mathrm{em}}\right)$ represents fluorescence intensity as a function of emission wavelength, $I(R U)$ represents fluorescence intensity of samples in RU, I(AU) represents raw fluorescence intensity of samples in Arbitrary Units (AU).

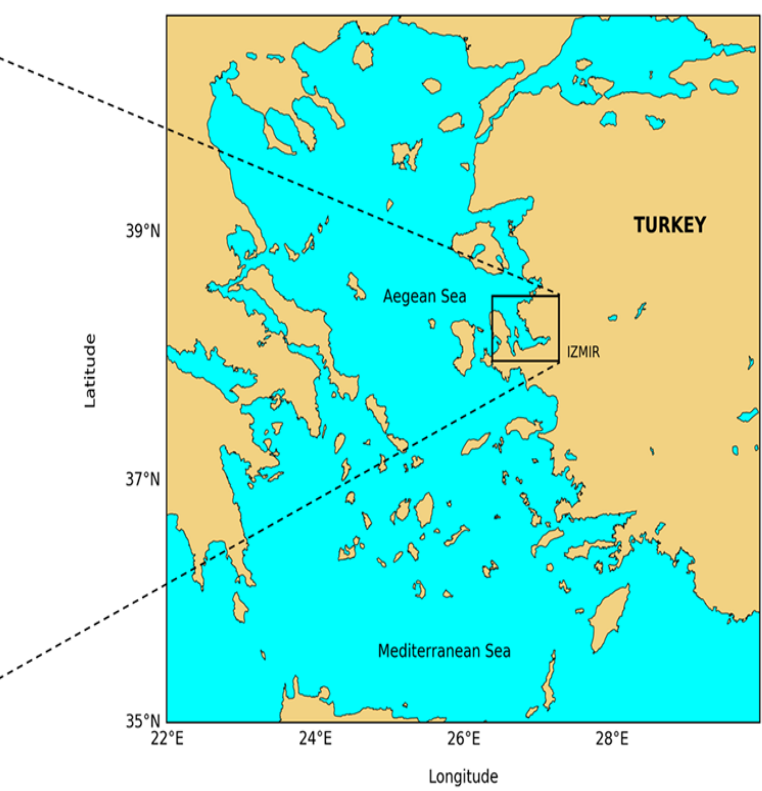

Table 1. Determination criteria of EEM peaks according to Coble (1996)

\begin{tabular}{cl}
\hline EEM peaks & Peak name (Wavelength range) \\
\hline A & UV humic-like (Ex:260, Em:380-460) \\
B & Tyrosine-like, protein-like (Ex:275, Em:310) \\
C & Visible humic-like (Ex:350, Em:420-480) \\
M & Marine humic-like (Ex:312, Em:380-420) \\
T & Tryptophan-like, protein-like (Ex:275, Em:340) \\
\hline
\end{tabular}

\section{Calculations of fluorescence indexes}

HIX and BIX are used to extract quantitative information on contributions of humic matter and autochthonous production to the fluorescence intensities of seawater samples. HIX was first introduced by Zsolnay et al. (1999) for estimating the humic matter content of DOM in soil samples. As a result of higher humification degree, $\mathrm{C} / \mathrm{H}$ ratio and aromaticity was increased (Lüttig, 1986; Stevenson, 1982) and a shift to longer emission wavelengths was observed (Chen et al., 2011; Huguet et al., 2009; Tam and Sposito, 1993; Zsolnay et al., 1999). HIX is defined as the ratio of spectral area under emission wavelengths of $435-480 \mathrm{~nm}$ to emission wavelengths of 300$345 \mathrm{~nm}$ at excitation wavelength of $254 \mathrm{~nm}$. HIX can be formulated as below (Eq. 3):

$\mathrm{HIX}=\frac{\int_{435}^{480} I\left(\lambda_{\mathrm{em}}\right) \mathrm{d} \lambda_{\mathrm{em}}}{\int_{300}^{345} I\left(\lambda_{\mathrm{em}}\right) \mathrm{d} \lambda_{\mathrm{em}}}$

where $I$ represents fluorescence intensity as a function of emission wavelength $\left(\lambda_{\mathrm{em}}\right)$. 
BIX was introduced by Huguet et al. (2009) for determination of the autochthonous biological activity and freshly produced DOM in natural water samples. While large BIX values indicate diagenetically unaltered DOM, numerator part of the fraction corresponds to microbially produced DOM, and denominator part represents highly decomposed DOM (Fellman et al., 2010; Lu et al., 2015; Wilson and Xenopoulos, 2009). It is calculated by dividing the fluorescence intensity at excitation wavelength of $310 \mathrm{~nm}$ and emission wavelength of $380 \mathrm{~nm}$ to the maximum emission intensity in the range of 420 $480 \mathrm{~nm}$ at excitation wavelength of $310 \mathrm{~nm}$ (Eq. 4).

$\mathrm{BIX}=\frac{I_{\lambda_{\mathrm{ex} 310} / \lambda_{\mathrm{em} 380}}}{\max _{420} \leq \lambda_{\mathrm{em}} \leq 480{ } \lambda_{\mathrm{ex} 310}}$

where / represents fluorescence intensity.

a)

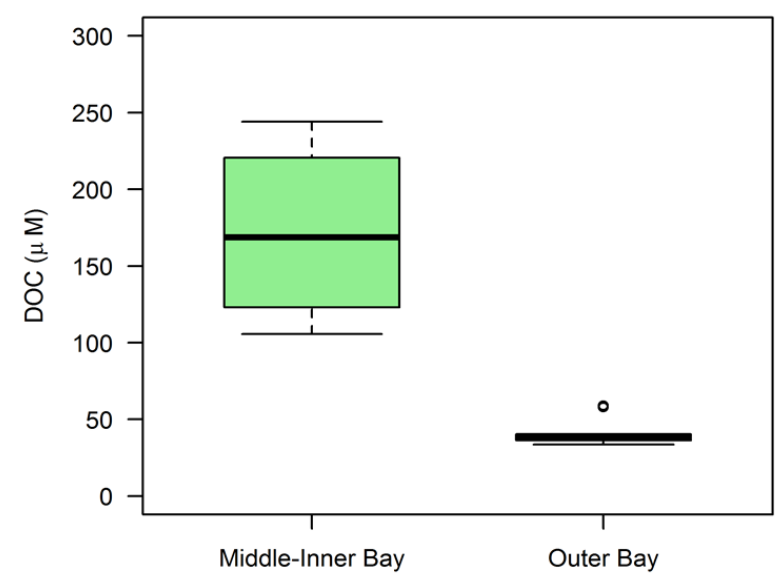

c)

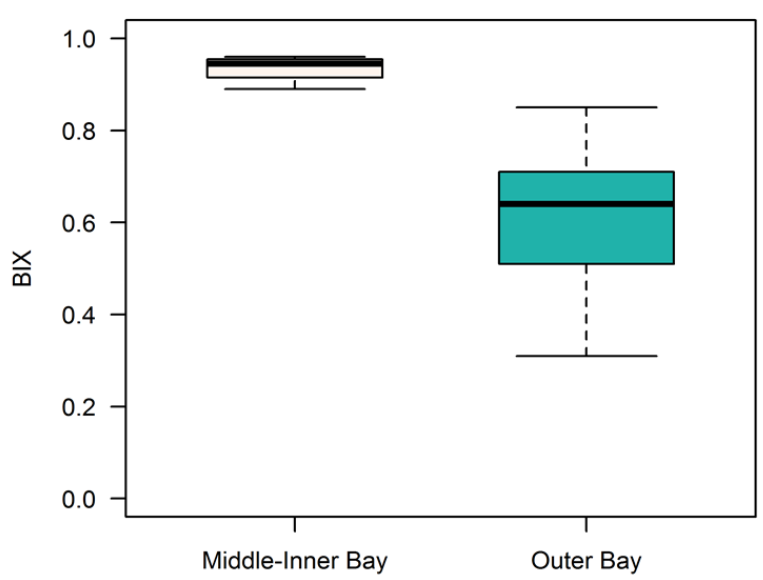

\section{Statistical analyses}

Statistical analyses were performed with $\mathrm{R}$ Statistical Computing Software, v3.3.1 (R Core Team, 2016). The Spearman's rank correlation test was performed between EEM peaks, HIX, BIX and DOC. Also, relationships between EEM peaks, HIX, BIX and DOC were investigated with linear regression analyses.

\section{RESULTS AND DISCUSSION}

The results of DOC, EEM peak intensities of CDOM components and fluorescence indexes ( $\mathrm{HIX}$ and $\mathrm{BIX}$ ) were given in Table 2. DOC concentrations were found in the range of 35.3-244.2 $\mu \mathrm{M}$ throughout the bay. DOC levels in the middle-inner bays (stations 1 and 2) observed higher compared to outer bay (stations 3-7) (Figure 2a). DOC concentrations found in this study were similar to the previous reports (56.1-121 $\mu \mathrm{M})$ for İzmir Bay (Kucuksezgin et al., 2005)

b)

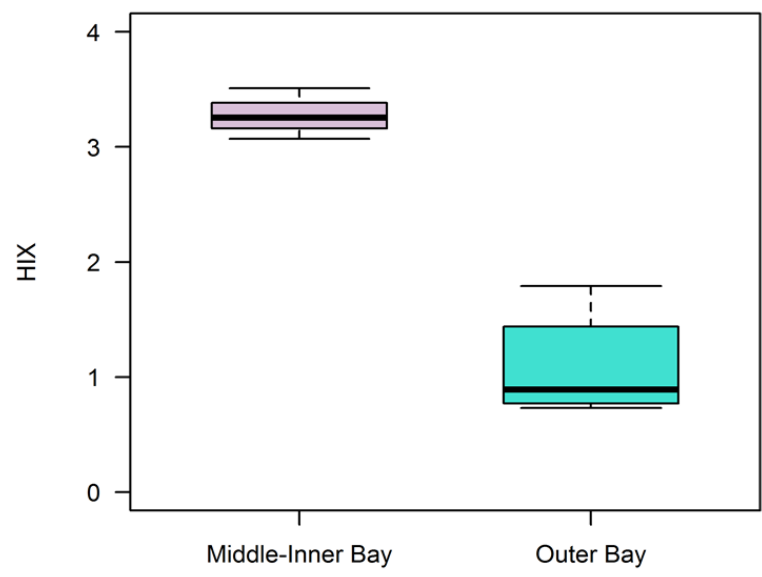

Figure 2. Distributions of $D O C, H I X$ and $B I X$ in the middle-inner and outer bays: a) DOC, b) HIX, and c) BIX 
Optical characterization of chromophoric dissolved organic matter at eutrophic and oligotrophic parts of a semi-enclosed bay (Izmir, Aegean Sea)

Table 2. DOC concentrations, fluorescent components of CDOM and descriptive fluorescence indexes (S: Surface, SS: Subsurface)

\begin{tabular}{|c|c|c|c|c|c|c|c|c|}
\hline Station & $\mathrm{DOC}(\mu \mathrm{M})$ & Peak M & Peak A & Peak C & Peak T & Peak B & HIX & $\mathrm{BIX}$ \\
\hline St1-S & 244.2 & 0.13 & 0.18 & 0.11 & 0.11 & 0.05 & 3.51 & 0.94 \\
\hline St1-SS & 206.6 & 0.14 & 0.18 & 0.10 & 0.09 & 0.06 & 3.26 & 0.95 \\
\hline St2-S & 140.3 & 0.09 & 0.14 & 0.08 & 0.07 & 0.05 & 3.25 & 0.89 \\
\hline St2-SS & 105.6 & 0.11 & 0.14 & 0.09 & 0.09 & 0.05 & 3.07 & 0.96 \\
\hline St3-S & 58.9 & 0.03 & 0.05 & 0.04 & 0.04 & 0.02 & 1.79 & 0.85 \\
\hline St3-SS & 42.7 & 0.03 & 0.05 & 0.02 & 0.02 & 0.02 & 1.58 & 0.68 \\
\hline St4-S & 45.4 & 0.01 & 0.02 & 0.02 & 0.02 & 0.01 & 0.77 & 0.37 \\
\hline St4-SS & 42.7 & 0.02 & 0.02 & 0.02 & 0.01 & 0.02 & 0.87 & 0.31 \\
\hline St5-S & 38.6 & 0.03 & 0.04 & 0.02 & 0.03 & 0.02 & 1.08 & 0.60 \\
\hline St5-SS & 46.7 & 0.03 & 0.03 & 0.02 & 0.02 & 0.01 & 1.44 & 0.73 \\
\hline St6-S & 58.9 & 0.02 & 0.03 & 0.02 & 0.02 & 0.01 & 0.79 & 0.68 \\
\hline St6-SS & 37.7 & 0.03 & 0.03 & 0.02 & 0.03 & 0.04 & 0.73 & 0.51 \\
\hline St7-S & 38.6 & 0.02 & 0.03 & 0.02 & 0.01 & 0.01 & 0.77 & 0.57 \\
\hline St7-SS & 35.3 & 0.01 & 0.02 & 0.02 & 0.01 & 0.01 & 0.91 & 0.71 \\
\hline
\end{tabular}

Raman normalized fluorescence intensities of EEM peaks decreased from inner to outer bay stations (Table 2). EEM spectrums of the samples were given in Figures 3 and 4 . Intensities of EEM peaks decreased in the order of A, M, C, T, and $B$ at station 1 and 2 . The intensities of peak $A$ at station 3 were slightly higher compared to other outer bay stations. On the other hand, EEM peak intensities were very similar to each other at outer bay stations. Results indicated the presence of higher humic-like (peaks A, C, and M) and protein-like (peaks $T$ and $B$ ) components at middle-inner bays than outer bay stations.

HIX and BIX indexes decreased from inner to outer bay stations (Figure 2b,c). HIX was between 0.73-3.51, whereas BIX ranged from 0.31 to 0.96 in the bay. According to scales of HIX defined by Huguet et al. (2009), HIX values in this study showed that the DOM in middle-inner bays (3.07-3.51) might be originated from biological or aquatic bacterial processes, but this character was weaker at outer bay stations (0.77-1.79).
According to BIX values (Huguet et al., 2009), DOM has strong autochthonous character at middle-inner bays (0.89-0.96) whereas DOM showed autochthonous character from low to strong levels at a wide range $(0.31-0.85)$ in outer bay.

Observation of relatively high HIX values in the middleinner bays could be linked to the presence of Melez stream (heavily polluted), other streams, rain run-offs and maritime activities at Izmir Bay. High HIX values at middle-inner bays might be related with humic matter inputs (humification degree) and stabilities of CDOM components (Bai et al., 2014; Chari et al., 2012; Huguet et al., 2009). Also, high BIX values indicated presence of freshly produced DOM from bacterial origin (Fellman et al., 2010; Lu et al., 2015; Wilson and Xenopoulos, 2009). According to HIX vs. BIX plot in Figure 5 , it was possible to distinguish CDOM characteristics of middle-inner bay stations from outer bay. High HIX and BIX values for CDOM might be resulted from high anthropogenic inputs, physicochemical characteristics and biological processes in middleinner bays. 

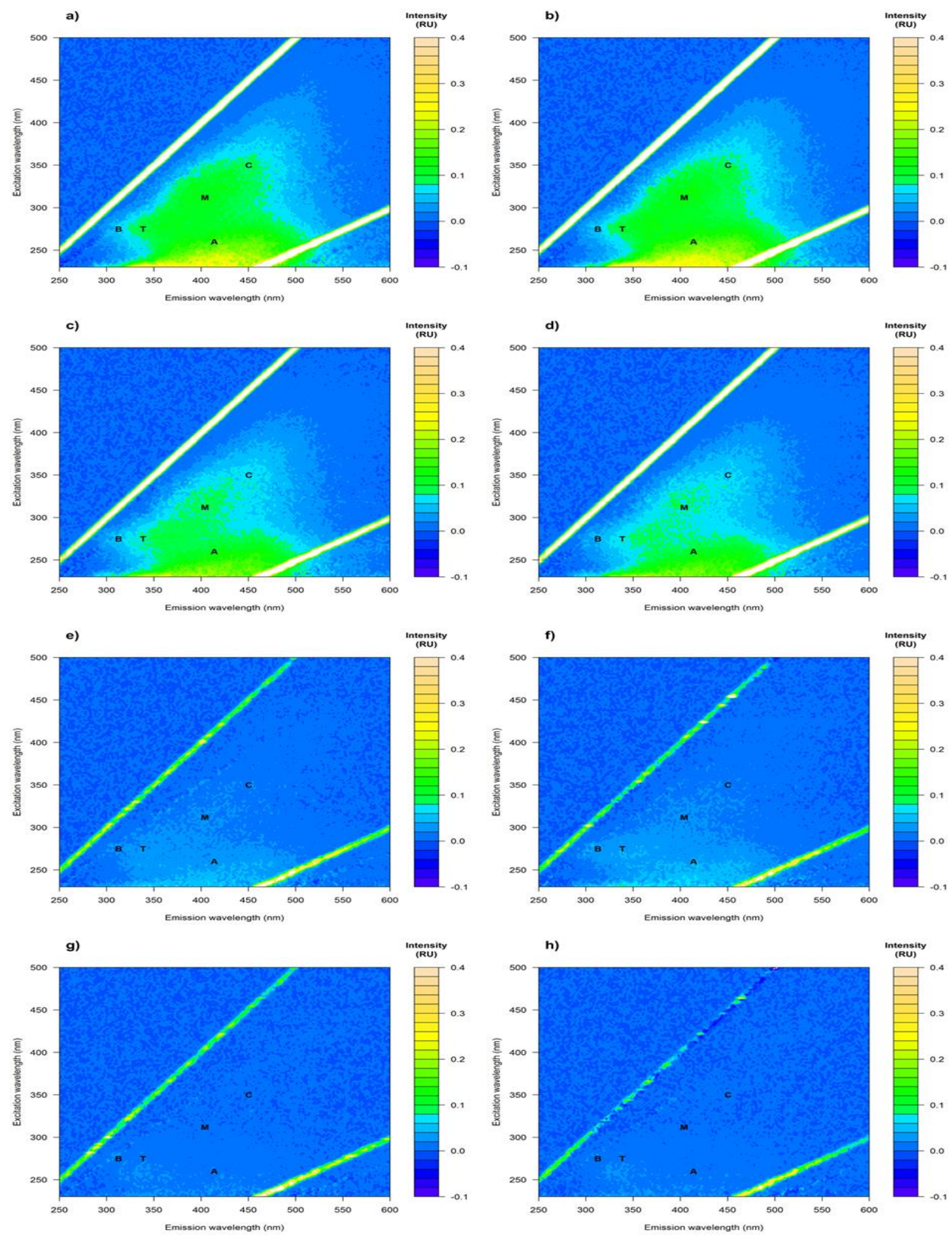

Figure 3. EEM plots for Station 1 to 4: a) St1-S, b) St1-SS, c) St2-S, d) St2-SS, e) St3-S, f) St3-SS, g) St4-S, and h) St4-SS (S: Surface, SS: Subsurface) 

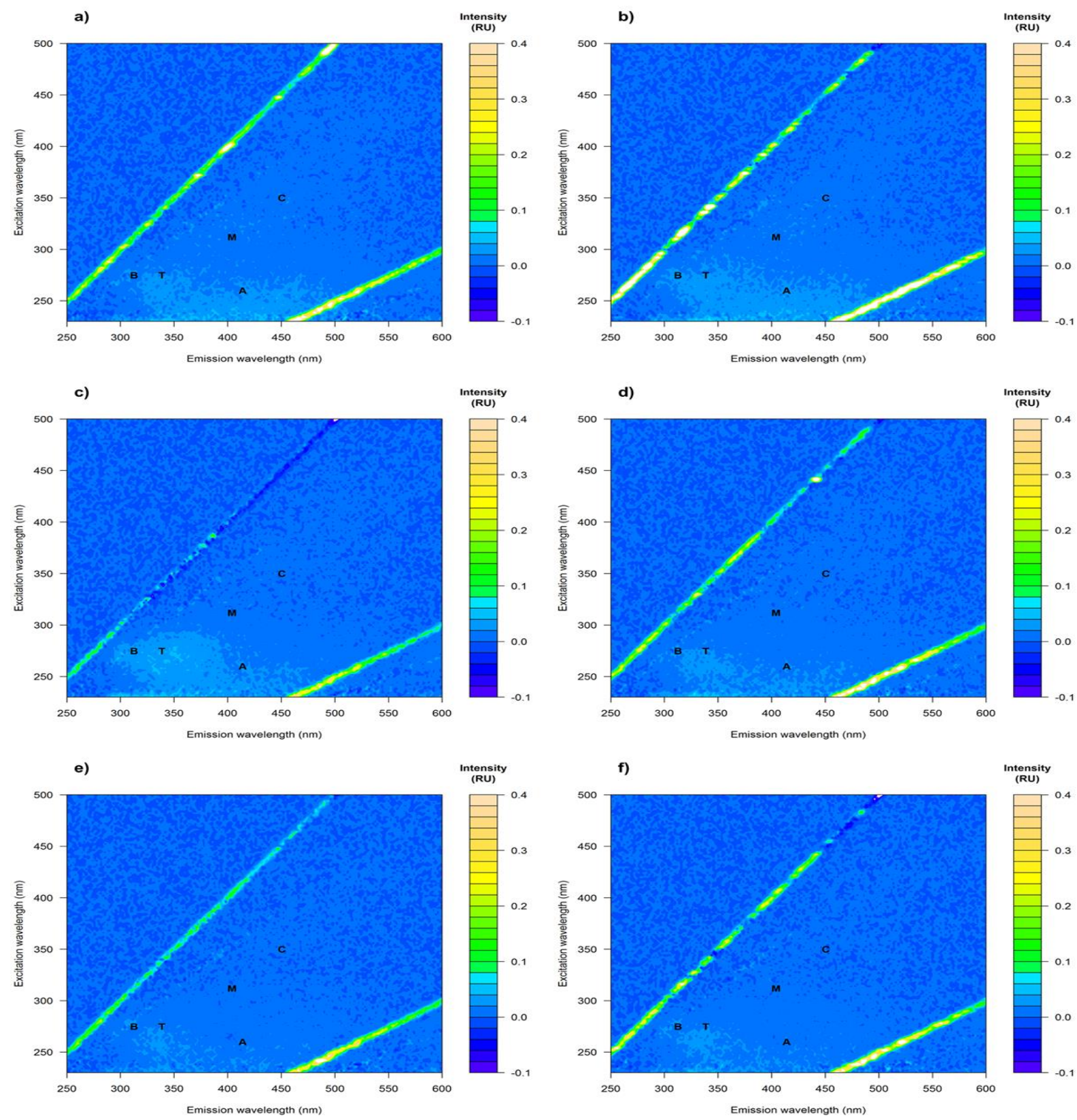

Figure 4. EEM plots for Station 5 to 7: a) St5-S, b) St5-SS, c) St6-S, d) St6-SS, e) St7-S, and f) S7-SS (S: Surface, SS: Subsurface)

Spearman's rank correlations between EEM peak intensities, HIX, BIX, total fluorescence intensities ( $\Sigma F L)$ and DOC concentrations were found highly positive $(p<0.05$, Table 3). Linear relationships between EEM peaks, HIX, BIX and DOC concentrations at middle-inner and outer bays were given in Figure 6 and Table 3.

According to linear regression between $\mathrm{DOC}$ and $\Sigma \mathrm{FL}$, the fluorescent fraction of DOM in the surface and subsurface waters of İzmir Bay were composed of highly fluorescent and slightly fluorescent fractions (Figure 6c). Also, humic-like (A, C, M) and tryptophan-like (T) EEM peaks were able to explain more than $85 \%$ of variation in DOC concentrations. Linear relationships between $\mathrm{HIX}$ and DOC concentrations (explaining $80 \%$ variation in DOC) indicated that humic matter has an important contribution to DOM.

On the other hand, correlation $(\rho=0.719, p=0.004)$ and linearity $\left(r^{2}=0.484, \quad p=0.005\right)$ between BIX and $D O C$ represented weaker contribution of autochthonous processes to DOM pool. As a result, DOM composition in Izmir Bay could be linked to humic matter inputs and in situ marine production processes. 


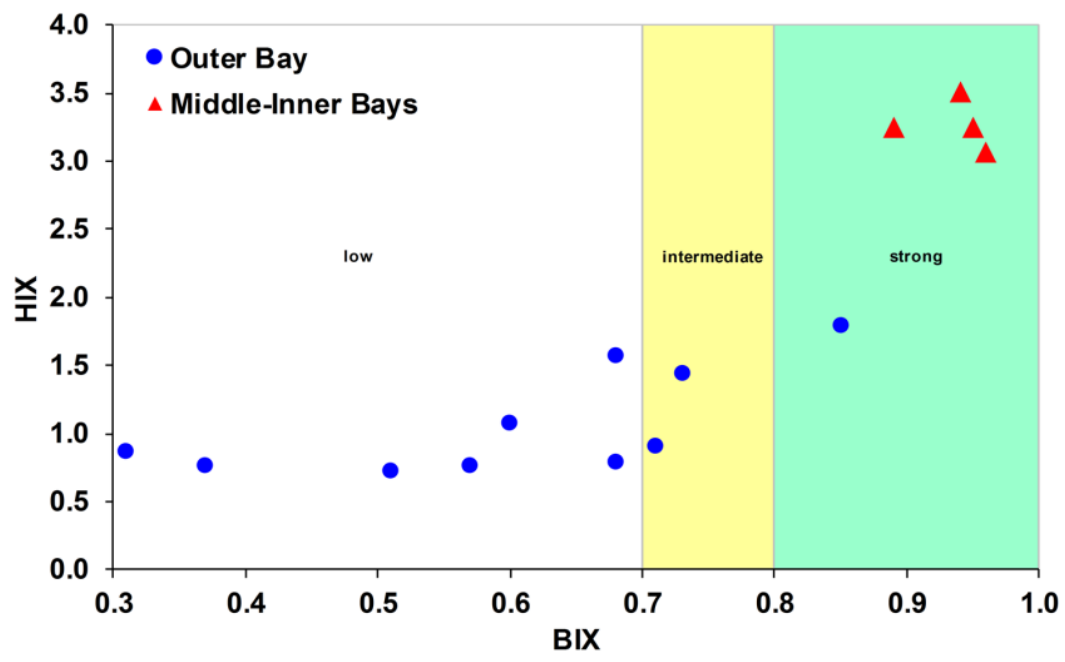

Figure 5. Relationships between HIX and BIX. Low, intermediate and strong indicates autochthonous character of DOM (Huguet et al. 2009)

Spectral ranges of EEM peaks found in this study were very similar to the peaks of CDOM components previously reported in the literature (Penru et al., 2013; Retelletti Brogi et al., 2015; Su et al., 2015; Zeri et al., 2014). Excitation and emission wavelengths of peak regions and corresponding CDOM components were compared with other studies in Table 4. In the North Aegean Sea and Marmara Sea, Zeri et al. (2014) have identified three PARAFAC components within CDOM corresponding to UV and visible humic-like (C1), marine humiclike (C2) and tyrosine-like (C3) peaks. Similar humic-like and protein-like peaks were also present in studies at the Northwestern Mediterranean Sea (Penru et al., 2013) and Tyrrhenian Sea (Retelletti Brogi et al., 2015). Humic-like peaks have been reported at coastal environments under the influences of terrestrial inputs and low salinity waters (Coble, 1996; Stedmon and Markager, 2005). Marine humic-like peaks have been associated with increased phytoplankton activity and autochthonous production (Coble, 1996; Murphy et al., 2008). Tyrosine and tryptophan-like peaks have been shown to originate from bacterial degradation of organic matter and these components are widely distributed along coastal waters (Coble, 1996; Stedmon et al., 2003; Yamashita et al., 2008).

Due to the low velocities of water masses inflowing and outflowing, inner part of İzmir Bay has been more heavily influenced from anthropogenic inputs. According to Sayin (2003), water mass renewal time for inner part was found as 3 months, whereas renewal time for outer bay was around 1-1.5 months. Similarly, Jiang et al. (2008) have reported the influence of water circulation on DOM transport. In middle-inner and outer bays, variations of EEM peak intensities, HIX and BIX (Figures 2-4) could be related to the influences of anthropogenic inputs and physico-chemical characteristics of water masses.

Table 3. Results of Spearman's rank correlation tests and linear regression analyses between EEM peaks, $\Sigma \mathrm{FL}, \mathrm{HIX}, \mathrm{BIX}$ and DOC

\begin{tabular}{lll}
\hline & Correlations with DOC & Linear Regression Equations \\
\hline Peak A & $\rho=0.744, p=0.002$ & {$[\mathrm{DOC}]=1044.9[\mathrm{~A}]+9.9, r^{2}=0.896, p=0.000$} \\
Peak B & $\rho=0.575, p=0.031$ & {$[\mathrm{DOC}]=2968.0[\mathrm{~B}]+1.0, r^{2}=0.654, p=0.000$} \\
Peak C & $\rho=0.843, p=0.000$ & {$[\mathrm{DOC}]=1826.9[\mathrm{C}]+3.3, r^{2}=0.888, p=0.000$} \\
Peak M & $\rho=0.701, p=0.005$ & {$[\mathrm{DOC}]=1382.3[\mathrm{M}]+12.5, r^{2}=0.873, p=0.000$} \\
Peak T & $\rho=0.751, p=0.002$ & {$[\mathrm{DOC}]=1828.4[\mathrm{~T}]+7.1, r^{2}=0.846, p=0.000$} \\
$\Sigma$ FL & $\rho=0.727, p=0.003$ & {$[\mathrm{DOC}]=332.6[\Sigma \mathrm{FL}]+5.8, r^{2}=0.877, p=0.000$} \\
HIX & $\rho=0.774, p=0.001$ & {$[\mathrm{DOC}]=56.1[\mathrm{HIX}]-13.9, r^{2}=0.796, p=0.000$} \\
BIX & $\rho=0.719, p=0.004$ & {$[\mathrm{DOC}]=226.1[\mathrm{BIX}]-75.9, r^{2}=0.484, p=0.005$} \\
\hline
\end{tabular}


a)

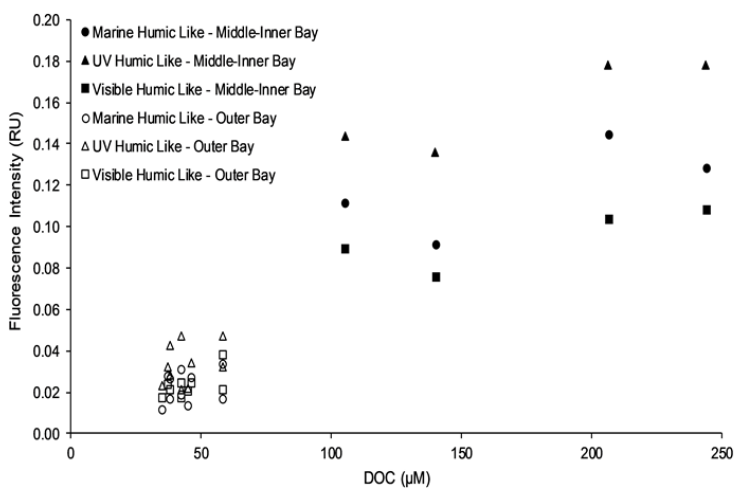

c)

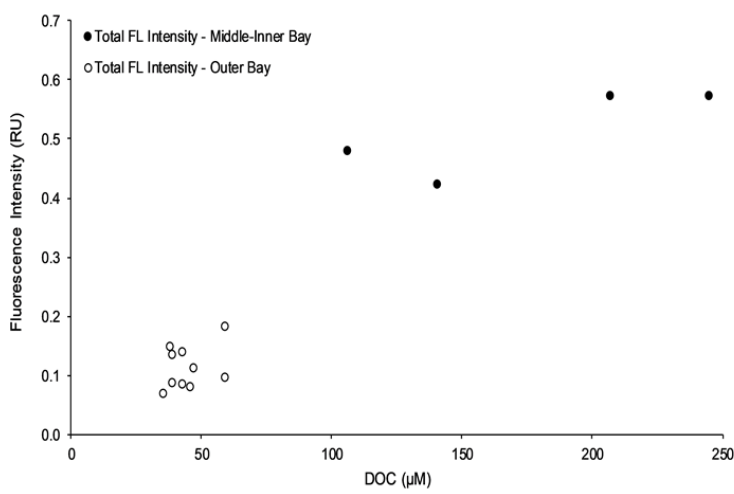

b)

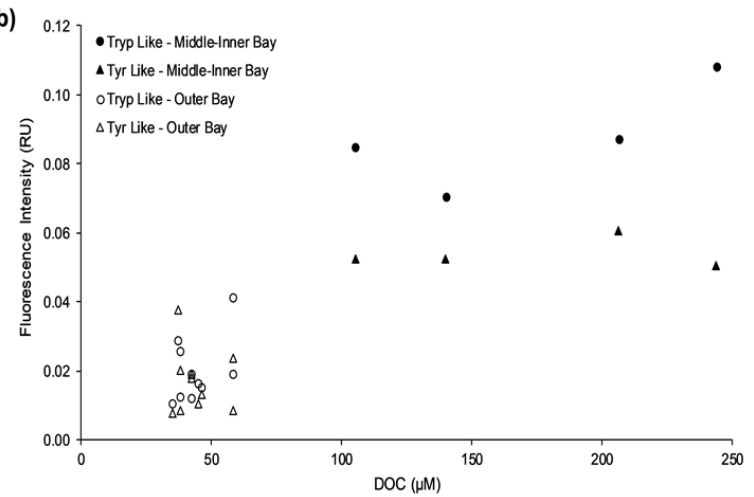

d)

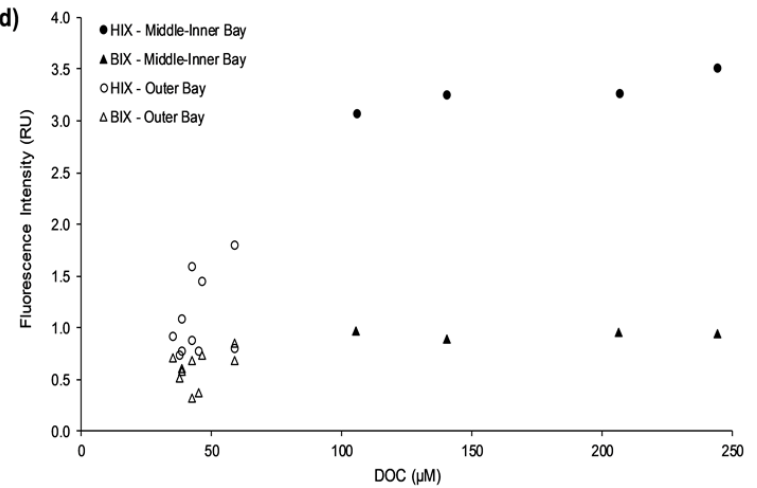

Figure 6. Linear relationships between DOC and a) Marine Humic-like, UV Humic-like and Visible Humic-like peaks, b) Tryptophan-like and Tyrosine-like peaks, and c) $\Sigma F L$, and d) HIX and BIX

Table 4. Characteristics of the EEM peaks identified in this study and their comparison with those of other studies

\begin{tabular}{|c|c|c|c|c|}
\hline $\begin{array}{l}\text { EEM Peaks } \\
\text { (Ex/Em) } \\
\text { (This Study) }\end{array}$ & $\begin{array}{l}\text { Marmara Sea; } \\
\text { North Aegean Sea } \\
\text { (Zeri et al., 2014) }\end{array}$ & $\begin{array}{l}\text { Northwestern } \\
\text { Mediterranean Sea } \\
\text { (Penru et al., 2013) }\end{array}$ & $\begin{array}{l}\text { Tyrrhenian Sea } \\
\text { (Retelletti Brogi et al., } \\
\text { 2015) } \\
\end{array}$ & $\begin{array}{l}\text { Southern Yellow Sea; } \\
\text { East China Sea } \\
\text { (Su et al., 2015) }\end{array}$ \\
\hline A $(260 / 380-460)$ & C1 $(<260(330) / 464)$ & III (220-250/380-580) & P1 (250/400-500) & C2 $(335 / 400)$ \\
\hline B $(275 / 310)$ & C3 $(270 / 308)$ & I (220-250/280-332) & P4 (270/315) & - \\
\hline C (350/420-480) & C1 $(<260(330) / 464)$ & V $(250-470 / 380-580)$ & P3 (350/450) & C1 $(360 / 440)$ \\
\hline M (312/380-420) & C2 $(<250,285 / 364)$ & IV $(250-470 / 280-380)$ & P2 (315/419) & - \\
\hline T $(275 / 340)$ & - & II (220-250/332-380) & P5 (280/341) & C4 $(280 / 360)$ \\
\hline
\end{tabular}

\section{CONCLUSION}

Optical characterization of chromophoric dissolved organic matter in Izmir Bay was studied by excitation-emission matrix spectroscopy in this study. Fluorescence measurements indicated the presence of higher humic-like (peaks $A, C$, and $\mathrm{M})$ and protein-like (peaks $\mathrm{T}$ and $\mathrm{B}$ ) components at eutrophic middle-inner bays. DOC concentrations, EEM peak intensities and HIX/BIX values increased from outer to inner bay. High $\mathrm{HIX}$ and BIX values in the middle-inner bays could be explained by the presence of higher humification degrees and freshly produced DOM with bacterial origin. In middle-inner bays, CDOM composition might be influenced from nutrient and DOM rich terrestrial inputs, and water renewal times. In conclusion, optical characterization of CDOM could be used for tracing fluorescent DOM components and determining different DOM sources (autochthonous or allochthonous) in further studies.

\section{ACKNOWLEDGEMENTS}

This research did not receive any specific grant from funding agencies in the public, commercial, or not-for-profit sectors. The samples in this study were collected during the cruise of a national research project (TUBITAK 113Y447) and the authors thank to TUBITAK. 


\section{REFERENCES}

Anderson, D.M., Glibert, P.M. \& Burkholder, J.M. (2002). Harmful algal blooms and eutrophication: Nutrient sources, composition, and consequences. Estuaries, 25(4), 704-726. DOI:10.1007/BF02804901

Aparicio, F.L., Nieto-Cid, M., Borrull, E., Calvo, E., Pelejero, C., Sala, M.M., Pinhassi, J., Gasol, J.M. \& Marrasé, C. (2016). Eutrophication and acidification: Do they induce changes in the dissolved organic matter dynamics in the coastal Mediterranean Sea? Science of the Total Environment, 563-564, 179-189. DOI:10.1016/j.scitotenv.2016.04.108

Bai, Y., Su, R. \& Shi. X. (2014). Assessing the dynamics of chromophoric dissolved organic matter in the southern Yellow Sea by excitationemission matrix fluorescence and parallel factor analysis (EEMPARAFAC). Continental Shelf Research, 88, 103-116. DOl:10.1016/j.csr.2014.07.011

Boyd, T.J. \& Osburn, C.L. (2004). Changes in CDOM fluorescence from allochthonous and autochthonous sources during tidal mixing and bacterial degradation in two coastal estuaries. Marine Chemistry, 89(14), 189-210. DOI:10.1016/j.marchem.2004.02.012

Brussaard, C.P.D. (2004). Algae, mortality rates, photosynthetic protists, Phycodnaviridae, virus. Journal of Eukaryotic Microbiology, 51(2), 125138. DOI:10.1111/j.1550-7408.2004.tb00537.x

Carlson, C.A. \& Hansell, D.A. (2015). DOM Sources, Sinks, Reactivity, and Budgets. In D.A. Hansell \& C.A. Carlson (Eds.), Biogeochemistry of Marine Dissolved Organic Matter (pp. 65-126). Florida, USA, Academic Press, 712 pp. DOI:10.1016/B978-0-12-405940-5.00003-0

Cauwet, G. (2002). DOM in the Coastal Zone. In D.A. Hansell \& C.A. Carlson (Eds.), Biogeochemistry of Marine Dissolved Organic Matter (pp. 579609). Florida, USA, Academic Press, 774 pp. DOI:10.1016/B978-012323841-2/50014-2

Chari, N.V.H.K., Sarma, N.S., Pandi, S.R. \& Murthy, K.N. (2012). Seasonal and spatial constraints of fluorophores in the midwestern Bay of Bengal by PARAFAC analysis of excitation emission matrix spectra. Estuarine Coastal and Shelf Science, 100, 162-171. DOI:10.1016/j.ecss.2012.01.012

Chen, H., Zheng, B., Song, Y. \& Qin, Y. (2011). Correlation between molecular absorption spectral slope ratios and fluorescence humification indices in characterizing CDOM. Aquatic Sciences 73(1), 103-112. DOI:10.1007/s00027-010-0164-5

Cloern, J.E. (2001). Our evolving conceptual model of the coastal eutrophication problem. Marine Ecology Progress Series, 210, 223-253. DOI:10.3354/meps210223

Coble, P.G., Green, S.A., Blough, N.V. \& Gagosian, R.B. (1990). Characterization of dissolved organic matter in the Black Sea by fluorescence spectroscopy. Nature, 348(6300), 432-435. DOI:10.1038/348432a0

Coble, P.G. (1996). Characterization of marine and terrestrial DOM in seawater using excitation-emission matrix spectroscopy. Marine Chemistry, 51(4), 325-346. DOI:10.1016/0304-4203(95)00062-3

Conley, D.J., Carstensen, J., Vaquer-Sunyer, R. \& Duarte, C.M. (2009). Ecosystem thresholds with hypoxia. In J.H. Andersen \& D.J. Conley (Eds.), Eutrophication in Coastal Ecosystems, Towards better understanding and management strategies (pp. 21-29). Dordrecht, Netherlands, Springer, 264 pp. DOI: 10.1007/978-90-481-3385-7_3

Couturier, M., Nozais, C. \& Chaillou, G. (2016). Microtidal subterranean estuaries as a source of fresh terrestrial dissolved organic matter to the coastal ocean. Marine Chemistry, 186, 46-57. DOI:10.1016/j.marchem.2016.08.001

Davidson, K., Gowen, R.J., Tett, P., Bresnan, E., Harrison, P.J., McKinney, A., Milligan, S., Mills, D.K., Silke, J. \& Crooks, A.M. (2012). Harmful algal blooms: How strong is the evidence that nutrient ratios and forms influence their occurrence? Estuarine Coastal and Shelf Science, 115, 399-413. DOI:10.1016/j.ecss.2012.09.019

Davidson, K., Gowen, R.J., Harrison, P.J., Fleming, L.E., Hoagland, P. \& Moschonas, G. (2014). Anthropogenic nutrients and harmful algae in coastal waters. Journal of Environmental Management, 146, 206-216. DOI:10.1016/j.jenvman.2014.07.002
Dixon, J.L., Osburn, C.L., Paerl, H.W. \& Peierls, B.L. (2014). Seasonal changes in estuarine dissolved organic matter due to variable flushing time and wind-driven mixing events. Estuarine Coastal and Shelf Science, 151, 210-220. DOI:10.1016/j.ecss.2014.10.013

Fellman, J.B., Hood, E. \& Spencer, R.G.M. (2010). Fluorescence spectroscopy opens new windows into dissolved organic matter dynamics in freshwater ecosystems: A review. Limnology and Oceanography, 55(6), 2452-2462. DOI:10.4319/lo.2010.55.6.2452

Gershey, R.M., Mackinnon, M.D., Williams, P.J. \& Moore, R.M. (1979). Comparison of three oxidation methods used for the analysis of dissolved organic carbon in seawater. Marine Chemistry, 7, 289-306. DOI:10.1016/0304-4203(79)90017-3

Guo, W., Stedmon, C.A., Han, Y., Wu, F., Yu, X. \& Hu, M. (2007). The conservative and non-conservative behavior of chromophoric dissolved organic matter in Chinese estuarine waters. Marine Chemistry, 107(3), 357-366. DOI:10.1016/j.marchem.2007.03.006

Hansell, D.A., Carlson, C.A., Repeta, D.J. \& Schlitzer, R. (2009). Dissolved Organic Matter in the Ocean: A Controversy Stimulates New Insights. Oceanography, 22, 202-211. DOI:10.5670/oceanog.2009.109

Hedges, J.I. (2002). Why Dissolved Organics Matter. In D.A. Hansell \& C.A. Carlson (Eds.), Biogeochemistry of Marine Dissolved Organic Matter (pp. 1-33). Florida, USA, Academic Press, 774 pp. DOI: 10.1016/B978-012323841-2/50003-8

Heisler, J., Glibert, P.M., Burkholder, J.M., Anderson, D.M., Cochlan, W., Dennison, W.C., Dortch, Q., Gobler, C.J., Heil, C.A., Humphries, E., Lewitus, A., Magnien, R., Marshall, H.G., Sellner, K., Stockwell, D.A., Stoecker, D.K. \& Suddleson, M. (2008). Eutrophication and harmful algal blooms: A scientific consensus. Harmful Algae, 8(1), 3-13. DOI:10.1016/j.hal.2008.08.006

Hong, H., Wu, J., Shang, S. \& Hu, C. (2005). Absorption and fluorescence of chromophoric dissolved organic matter in the Pearl River Estuary, South China. Marine Chemistry, 97(1-2), 78-89. DOI:10.1016/j.marchem.2005.01.008

Huguet, A., Vacher, L., Relexans, S., Saubusse, S., Froidefond, J.M. \& Parlanti, E. (2009). Properties of fluorescent dissolved organic matter in the Gironde Estuary. Organic Geochemistry, 40(6), 706-719. DOI:10.1016/j.orggeochem.2009.03.002

Jessen, C., Bednarz, V.N., Rix, L., Teichberg, M. \& Wild, C. (2015). Marine Eutrophication. In H.R. Armon \& O. Hänninen (Eds.), Environmental Indicators (pp. 177-203). Dordrecht, Netherlands, Springer, 1068 pp. DOI: 10.1007/978-94-017-9499-2_11

Jiang, F., Lee, F.S.C., Wang, X. \& Dai, D. (2008). The application of Excitation/Emission Matrix spectroscopy combined with multivariate analysis for the characterization and source identification of dissolved organic matter in seawater of Bohai Sea, China. Marine Chemistry, 110(12), 109-119. DOI:10.1016/j.marchem.2008.02.010

Kontas, A., Kucuksezgin, F., Altay, O. \& Uluturhan, E. (2004). Monitoring of eutrophication and nutrient limitation in the Izmir Bay (Turkey) before and after Wastewater Treatment Plant. Environment International, 29(8), 1057-1062. DOI:10.1016/S0160-4120(03)00098-9

Korak, J.A., Dotson, A.D., Summers, R.S. \& Rosario-Ortiz, F.L. (2014). Critical analysis of commonly used fluorescence metrics to characterize dissolved organic matter. Water Research, 49, 327-338. DOl:10.1016/j.watres.2013.11.025

Korpinen, S. \& Bonsdorff, E. (2015). Eutrophication and hypoxia: impacts of nutrient and organic enrichment. In T.P. Crowe \& C.L.J. Fridin (Eds.), Marine Ecosystems: Human Impacts on Biodiversity, Functioning and Services (pp. 202-243). Cambridge, UK, Cambridge University Press, 416 pp. DOI: $10.1017 /$ CBO9781139794763.008

Kowalczuk, P., Cooper, W.J., Whitehead, R.F., Durako, M.J. \& Sheldon, W. (2003). Characterization of CDOM in an organic-rich river and surrounding coastal ocean in the South Atlantic Bight. Aquatic Sciences, 65(4), 384-401. DOI:10.1007/s00027-003-0678-1 
Kowalczuk, P., Cooper, W.J., Durako, M.J., Kahn, A.E., Gonsior, M. \& Young, H. (2010). Characterization of dissolved organic matter fluorescence in the South Atlantic Bight with use of PARAFAC model: Relationships between fluorescence and its components, absorption coefficients and organic carbon concentrations. Marine Chemistry, 118(1-2), 22-36. DOl:10.1016/j.marchem.2009.10.002

Kowalczuk, P., Sagan, S., Zabłocka, M. \& Borzycka, K. (2015). Mixing anomaly in deoxygenated Baltic Sea deeps indicates benthic flux and microbial transformation of chromophoric and fluorescent dissolved organic matter. Estuarine Coastal and Shelf Science, 163(B), 206-217. DOI:10.1016/j.ecss.2015.06.027

Kucuksezgin, F., Kontas, A., Altay, O. \& Uluturhan, E. (2005). Elemental composition of particulate matter and nutrient dynamics in the Izmir Bay (Eastern Aegean). Journal of Marine Systems, 56(1), 67-84. DOI:10.1016/j.jmarsys.2005.01.002

Lapworth, D.J. \& Kinniburgh, D.G. (2009). An R script for visualising and analysing fluorescence excitation-emission matrices (EEMs). Computers and Geosciences, 35(10), 2160-2163. DOI:10.1016/j.cageo.2008.10.013

Libes, S.M. (2009). Introduction to Marine Biogeochemistry. California, USA, Academic Press, $928 \mathrm{pp}$.

Lønborg, C., Yokokawa, T., Herndl, G.J. \& Álvarez-Salgado, X.A. (2015). Production and degradation of fluorescent dissolved organic matter in surface waters of the eastern north Atlantic ocean. Deep Sea Research Part I, 96, 28-37. DOI:10.1016/j.dsr.2014.11.001

Lu, Y.H., Edmonds, J.W., Yamashita, Y., Zhou, B., Jaegge, A. \& Baxley, M. (2015). Spatial variation in the origin and reactivity of dissolved organic matter in Oregon-Washington coastal waters. Ocean Dynamics, 65(1), 17-32. DOI:10.1007/s10236-014-0793-7

Lüttig, G. (1986). Plants to peat: the process of humification. In C.H. Fuchsman (Eds.), Peat and Water, Aspects of water retention and dewatering in peat (pp. 9-19). Amsterdam, Netherlands, Springer, 374 pp.

Mopper, K., Zhou, X., Kieber, R.J., Kieber, D.J., Sikorski, R.J. \& Jones, R.D. (1991). Photochemical degradation of dissolved organic carbon and its impact on the oceanic carbon cycle. Nature, 353(6339), 60-62. DOI:10.1038/353060a0

Motegi, C., Nagata, T., Miki, T., Weinbauer, M.G., Legendre, L. \& Rassoulzadegand, F. (2009). Viral control of bacterial growth efficiency in marine pelagic environments. Limnology and Oceanography, 54(6), 1901-1910. DOI:10.4319/lo.2009.54.6.1901

Murphy, K.R., Stedmon, C.A., Waite, T.D. \& Ruiz, G.M. (2008). Distinguishing between terrestrial and autochthonous organic matter sources in marine environments using fluorescence spectroscopy. Marine Chemistry, 108(1-2), 40-58. DOl:10.1016/j.marchem.2007.10.003

Murphy, K.R., Butler, K.D., Spencer, R.G.M., Stedmon, C.A., Boehme, J.R. \& Aiken, G.R. (2010). Measurement of Dissolved Organic Matter Fluorescence in Aquatic Environments: An Interlaboratory Comparison. Environmental Science and Technology, 44(24), 9405-9412. DOI:10.1021/es102362t

Murphy, K.R., Stedmon, C.A., Graeber, D. \& Bro, R. (2013). Fluorescence spectroscopy and multi-way techniques. PARAFAC. Analytical Methods, 5(23), 6557-6566. DOI:10.1039/C3AY41160E

Nelson, N.B., Carlson, C.A. \& Steinberg, D.K. (2004). Production of chromophoric dissolved organic matter by Sargasso Sea microbes. Marine Chemistry, 89(1-4), 273-287. DOI:10.1016/j.marchem.2004.02.017

Nieto-Cid, M., Álvarez-Salgado, X.A. \& Pérez, F.F. (2006). Microbial and photochemical reactivity of fluorescent dissolved organic matter in a coastal upwelling system. Limnology and Oceanography, 51(3), 13911400. DOI:10.4319//0.2006.51.3.1391

Ortega-Retuerta, E., Frazer, T.K., Duarte, C.M., Ruiz-Halpern, S., TovarSánchez, A., Arrieta, J.M. \& Rechea, I. (2009). Biogeneration of chromophoric dissolved organic matter by bacteria and krill in the Southern Ocean. Limnology and Oceanography, 54(6), 1941-1950. DOI:10.4319/lo.2009.54.6.1941
Ozkan, E.Y., Kocatas, A. \& Buyukisik, B. (2008). Nutrient dynamics between sediment and overlying water in the inner part of Izmir Bay, Eastern Aegean. Environmental Monitoring and Assessment, 143(1), 313-325. DOI:10.1007/s10661-007-9984-8

Penru, Y., Simon, F.X., Guastalli, A.R., Esplugas, S., Uorens, J. \& Balg, S. (2013). Characterization of natural organic matter from Mediterranean coastal seawater. Journal of Water Supply: Research and Technology AQUA, 62(1), 42-51. DOI:10.2166/aqua.2013.113

R Core Team. (2016). R: A Language and Environment for Statistical Computing, R Foundation for Statistical Computing, Vienna, Austria, https://www.r-project.org.

Retelletti Brogi, S., Gonnelli, M., Vestri, S. \& Santinelli, C. (2015). Biophysical processes affecting DOM dynamics at the Arno river mouth (Tyrrhenian Sea). Biophysical Chemistry, 197, 1-9. DOI:10.1016/j.bpc.2014.10.004

Ridgwell, A. \& Arndt, S. (2015). Why Dissolved Organics Matter: DOC in Ancient Oceans and Past Climate Change. In D.A. Hansell \& C.A. Carlson (Eds.), Biogeochemistry of Marine Dissolved Organic Matter (pp. 1-33). Florida, USA, Academic Press, 712 pp.

DOI: 10.1016/B978-0-12-405940-5.00001-7

Romera-Castillo, C., Sarmento, H., Álvarez-Salgado, X.A., Gasol, J.M. \& Marrasé, C. (2011a). Net Production and Consumption of Fluorescent Colored Dissolved Organic Matter by Natural Bacterial Assemblages Growing on Marine Phytoplankton Exudates. Applied and Environmental Microbiology, 77(21), 7490-7498. DOI:10.1128/AEM.00200-11

Romera-Castillo, C., Nieto-Cid, M., Castro, C.G., Marrasé, C., Largier, J., Barton, E.D. \& Álvarez-Salgado, X.A. (2011b). Fluorescence: Absorption coefficient ratio - Tracing photochemical and microbial degradation processes affecting coloured dissolved organic matter in a coastal system. Marine Chemistry, 125,(1-4), 26-38. DOI:10.1016/j.marchem.2011.02.001

Romera-Castillo, C., Álvarez-Salgado, X.A., Galí, M., Gasol, J.M. \& Marrasé, C. (2013). Combined effect of light exposure and microbial activity on distinct dissolved organic matter pools. A seasonal field study in an oligotrophic coastal system (Blanes Bay, NW Mediterranean). Marine Chemistry, 148, 44-51. DOI:10.1016/j.marchem.2012.10.004

Sala, M.M. \& Güde, H. (2004). Ectoenzymatic activities and heterotrophic bacteria decomposing detritus. Archives of Hydrobiology, 160(3), 289303. DOI:10.1127/0003-9136/2004/0160-0289

Santos, L., Santos, E.B.H., Dias, J.M., Cunha, A. \& Almeida, A. (2014). Photochemical and microbial alterations of DOM spectroscopic properties in the estuarine system Ria de Aveiro. Photochemical and Photobiological Sciences, 13(8), 1146-1159. DOI:10.1039/C4PP00005F

Sarmento, H., Romera-Castillo, C., Lindh, M., Pinhassi, J., Sala, M.M., Gasol, J.M., Marrase, C. \& Taylor, G.T. (2013). Phytoplankton species-specific release of dissolved free amino acids and their selective consumption by bacteria. Limnology and Oceanography, 58(3), 1123-1135. DOI:10.4319/lo.2013.58.3.1123

Sayin, E. (2003). Physical features of the Izmir Bay. Continental Shelf Research, 23(10), 957-970. DOI:10.1016/S0278-4343(03)00083-9

Schreurs, W. (1978). An automated colorimetric method for the determination of disolved organic carbon in seawater by U.V. destruction. Hydrobiological Bulletin Amsterdam, 12, 137-142. DOI:10.1007/BF02260715

Sellner, K.G., Doucette, G.J. \& Kirkpatrick, G.J. (2003). Harmful algal blooms: causes, impacts and detection. Journal of Industrial Microbiology and Biotechnology, 30(7), 383-406. DOI:10.1007/s10295-003-0074-9

Stedmon, C.A., Markager, S. \& Bro, R. (2003). Tracing dissolved organic matter in aquatic environments using a new approach to fluorescence spectroscopy. Marine Chemistry, 82(3-4), 239-254. DOI:10.1016/S0304-4203(03)00072-0

Stedmon, C.A. \& Markager, S. (2005). Tracing the production and degradation of autochthonous fractions of dissolved organic matter by fluorescence analysis. Limnology and Oceanography, 50(5), 1415-1426. DOI:10.4319/lo.2005.50.5.1415 
Stevenson, F.J. (1982). Humus Chemistry. New York, USA, Wiley, 443 pp.

Su, R., Bai, Y., Zhang, C. \& Shi, X. (2015). The assessment of the spatial and seasonal variability of chromophoric dissolved organic matter in the Southern Yellow Sea and the East China Sea. Marine Pollution Bulletin, 100(1), 523-533. DOI:10.1016/j.marpolbul.2015.09.002

Sulzberger, B. \& Durisch-Kaiser, E. (2009). Chemical characterization of dissolved organic matter (DOM): A prerequisite for understanding UVinduced changes of DOM absorption properties and bioavailability. Aquatic Sciences, 71(2), 104-126. DOI:10.1007/s00027-008-8082-5

Sun, Q., Wang, C., Wang, P., Hou, J. \& Ao, Y. (2014). Absorption and fluorescence characteristics of chromophoric dissolved organic matter in the Yangtze Estuary. Environmental Science and Pollution Research, 21(5), 3460-3473. DOI:10.1007/s11356-013-2287-4

Sunlu, U., Buyukisik, H.B., Koray, T., Brockel, K., Sunlu, F.S., Sever, T.M., Aydın, H., Aksu, M., Aydın, A. \& Orçun, E. (2007). The effects of Izmir Big Channel waste water treatment project to the lower trophic level of Izmir Bay (Aegean Sea, Turkey). The Scientific and Technical Research Council of Turkey (TUBITAK-CAYDAG), Project No:102Y116, Final Report. 253p. (in Turkish).

Sunlu, F.S., Sunlu, U., Buyukisik, B., Kukrer, S. \& Aksu, M. (2011). Effects of Wastewater Treatment Plant on Water Column and Sediment Quality in Izmir Bay (Eastearn Aegean Sea). In F.S.G. Einschlag (Eds.), Waste Water - Evaluation and Management (pp. 253-268). InTech, 482 pp.

Sunlu, F.S., Sunlu, U., Buyukisik, B., Kukrer, S. \& Uncumusaoglu, A. (2012). Nutrient and Chlorophyll a Trends after Wastewater Treatment Plant in Izmir Bay (Eastern Aegean Sea). Journal of Animal and Veterinary Advances, 11(1), 113-123. DOI:10.3923/javaa.2012.113.123

Tam, S.C. \& Sposito, G. (1993). Fluorescence spectroscopy of aqueous pine litter extracts: effects of humification and aluminium complexation. Journal of Soil Science, 44(3), 513-524.

DOI:10.1111/j.1365-2389.1993.tb00473.x

Tedetti, M., Cuet, P., Guigue, C. \& Goutx, M. (2011). Characterization of dissolved organic matter in a coral reef ecosystem subjected to anthropogenic pressures (La Réunion Island, Indian Ocean) using multidimensional fluorescence spectroscopy. Science of the Total Environment, 409(11), 2198-2210. DOI:10.1016/j.scitotenv.2011.01.058

Tzortziou, M., Zeri, C., Dimitriou, E., Ding, Y., Jaffé, R., Anagnostou, E., Pitta, E. \& Mentzafou, A. (2015). Colored dissolved organic matter dynamics and anthropogenic influences in a major transboundary river and its coastal wetland. Limnology and Oceanography, 60(4), 1222-1240. DOI:10.1002/Ino.10092

Vähätalo, A.V. \& Wetzel, R.G. (2004). Photochemical and microbial decomposition of chromophoric dissolved organic matter during long (months-years) exposures. Marine Chemistry, 89(1-4), 313-326. DOI:10.1016/j.marchem.2004.03.010

Wang, Y., Zhang, D., Shen, Z., Chen, J. \& Feng, C. (2014). Characterization and spacial distribution variability of chromophoric dissolved organic matter (CDOM) in the Yangtze Estuary. Chemosphere, 95, 353-362. DOI:10.1016/j.chemosphere.2013.09.044

Wilson, H.F. \& Xenopoulos, M.A. (2009). Effects of agricultural land use on the composition of fluvial dissolved organic matter. Nature Geosciences, 2(1), 37-41. DOI:10.1038/ngeo391

Yamashita, Y., Jaffé, R., Maie, N. \& Tanoue, E. (2008). Assessing the dynamics of dissolved organic matter (DOM) in coastal environments by excitation emission matrix fluorescence and parallel factor analysis (EEMPARAFAC). Limnology and Oceanography, 53(5), 1900-1908. DOI:10.4319/lo.2008.53.5.1900

Yamashita, Y. \& Tanoue, E. (2003). Distribution and alteration of amino acids in bulk DOM along a transect from bay to oceanic waters. Marine Chemistry, 82(3-4), 145-160. DOI:10.1016/S0304-4203(03)00049-5

Yang, L., Chen, C.T.A., Lui, H.K., Zhuang, W.E. \& Wang, B.J. (2016). Effects of microbial transformation on dissolved organic matter in the east Taiwan Strait and implications for carbon and nutrient cycling. Estuarine Coastal and Shelf Science, 180, 59-68. DOI:10.1016/j.ecss.2016.06.021

Zeri, C., Besiktepe, S., Giannakourou, A., Krasakopoulou, E., Tzortziouc, V., Tsoliakos, D., Pavlidoua, A., Mousdis, G., Pitta, E., Scoullos, M. \& Papathanassiou, E. (2014). Chemical properties and fluorescence of DOM in relation to biodegradation in the interconnected Marmara-North Aegean Seas during August 2008. Journal of Marine Systems, 135, 124136. DOI:10.1016/j.jmarsys.2013.11.019

Zhang, Y., Liu, X., Osburn, C.L., Wang, M., Qin, B. \& Zhou., Y. (2013). Photobleaching Response of Different Sources of Chromophoric Dissolved Organic Matter Exposed to Natural Solar Radiation Using Absorption and Excitation-Emission Matrix Spectra. PLOS ONE, 8(10), 114. DOI: 10.1371 /journal.pone.0077515

Zsolnay, A., Baigar, E., Jimenez, M., Steinweg, B. \& Saccomandi, F. (1999). Differentiating with fluorescence spectroscopy the sources of dissolved organic matter in soils subjected to drying. Chemosphere, 38(1), 45-50. DOI:10.1016/S0045-6535(98)00166-0 